элементы традиционной одежды в нашу повседневную одежду, путем стилизациимоделировании.

\title{
Сохранение функции голосового аппарата как залог успешной и долголетней деятельности преподавателей ГБПОУ РС (Я) «Нерюнгринский медицинский колледж»
}

Галанцева Ю.Ю., студентка, Нерюнгринский медицинский колледж, 2. Нерюнгри

Научный руководитель: преподаватель Лукина О.В.

Голос - это один из основных инструментов, необходимых для осуществления вербального общения. При помощи голоса мы завязываем социальные контакты. И если с голосом происходят какие-то изменения или он «пропадает», то это приводит к нарушению общения. У нас возник интерес к более подробному исследованию данной проблемы, с которой рано или поздно, в той или иной мере сталкивается большинство преподавателей средне - специальных и высших учебных заведений, а также педагогических работников детских дошкольных и средних общеобразовательных учреждений, которые ежедневно сталкиваются с речевой нагрузкой.

Полноценная деятельность людей коммуникативных профессий во многом зависит от работоспособности их голосового аппарата и качества голоса, от умения правильно и эффективно владеть им в профессиональных целях. Считается, что голосовой аппарат профессионала может работать в нагрузочном режиме не менее 4 академических часов в день ежедневно без утраты качества голоса.

Анкетирование преподавательского состава ГБПОУ РС (Я) «Нерюнгринский медицинский колледж»

Специально для всего преподавательского состава медицинского колледжа нами была разработана тематическая анкета из 16 вопросов, ответы на которые наиболее полно, по - нашему мнению, должны отразить как профессиональную деятельность преподавателей, так и имеющиеся проблемы с деятельностью речевого аппарата, с которым, возможно, сталкиваются педагоги во время учебных занятий, а также предпринимаемые меры профилактики по потере голоса. Анкетирование проводили в группы «СД -32» специальности «Сестринское дело». В исследовании принял участие весь преподавательский состав Нерюнгринского медицинского колледжа, численность которых составила 20 человек (100\% охват). Основываясь на полученных данных, мы составили графические изображения суммарных данных (рис.1). 


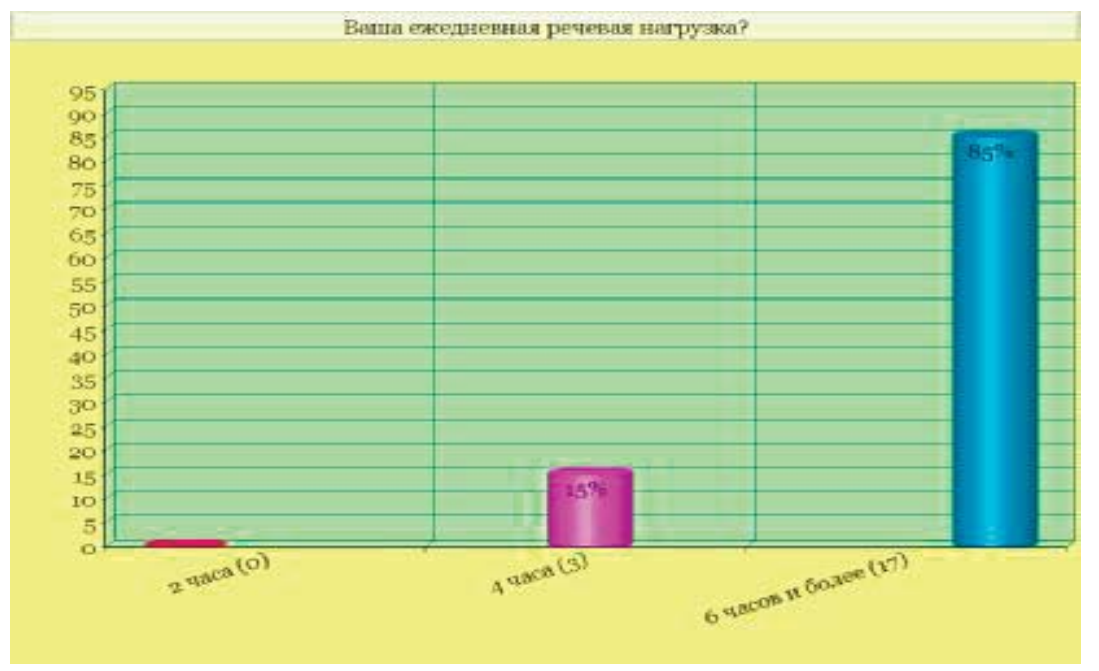

Рис. 1. К вопросу: «Ваша ежедневная рабочая нагрузка?»

Выводы: учитывая, что Нерюнгринский медицинский колледж - это средне профессиональное учебное заведение и педагогический состав коллектива представлен преподавателями специальных дисциплин, а также тот факт, что годовая рабочая нагрузка очень весома, то продолжительность рабочего дня преподавателя составляет более 6 часов (85\%). Преподавательская деятельность не ограничивается только лишь чтением лекций и ведением практических занятий. Такая общественная нагрузка преподавателя, как кураторство, руководство профессиональной цикловой комиссией также заставляет преподавателя уделять больше времени своей рабочей деятельности (рис.2).

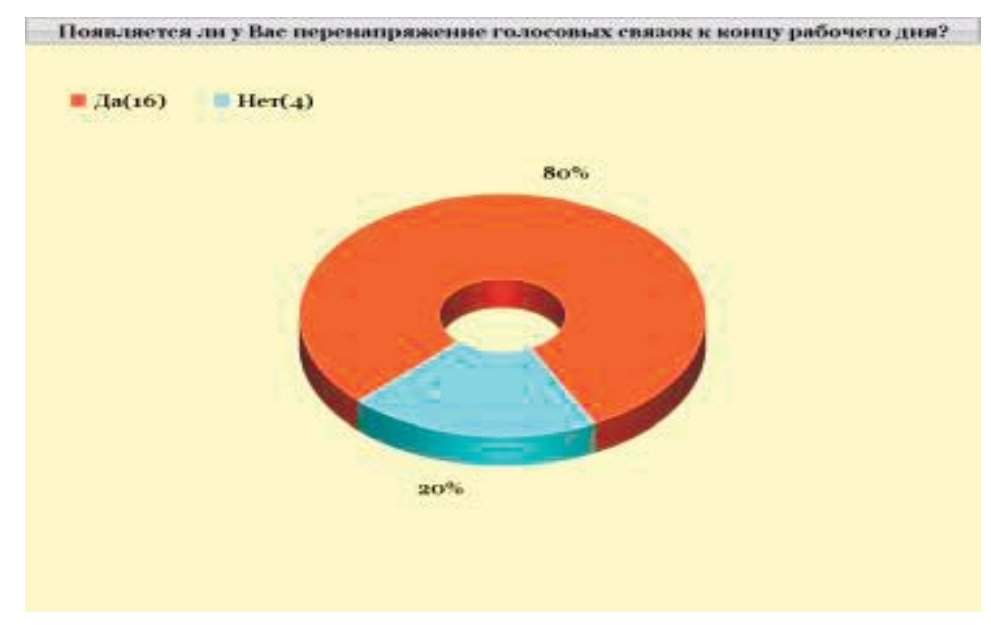

Рис. 2. К вопросу: «Появляется ли у вас перенапряжение голосовых связок к концу рабочего дня?»

Выводы: у подавляющего числа преподавателей медицинского колледжа (80\%) отмечаем наличие усталости голосового аппарата к концу рабочего дня. Это в очередной раз доказывает, что труд преподавателя очень непрост и указывает на то, что педагоги трудятся с большой самоотдачей.

Анализируя полученные данные, можно отметить то, что у более половины всего состава преподавателей Нерюнгринского медицинского колледжа (55\%) случалась потеря голоса (рис.3). 


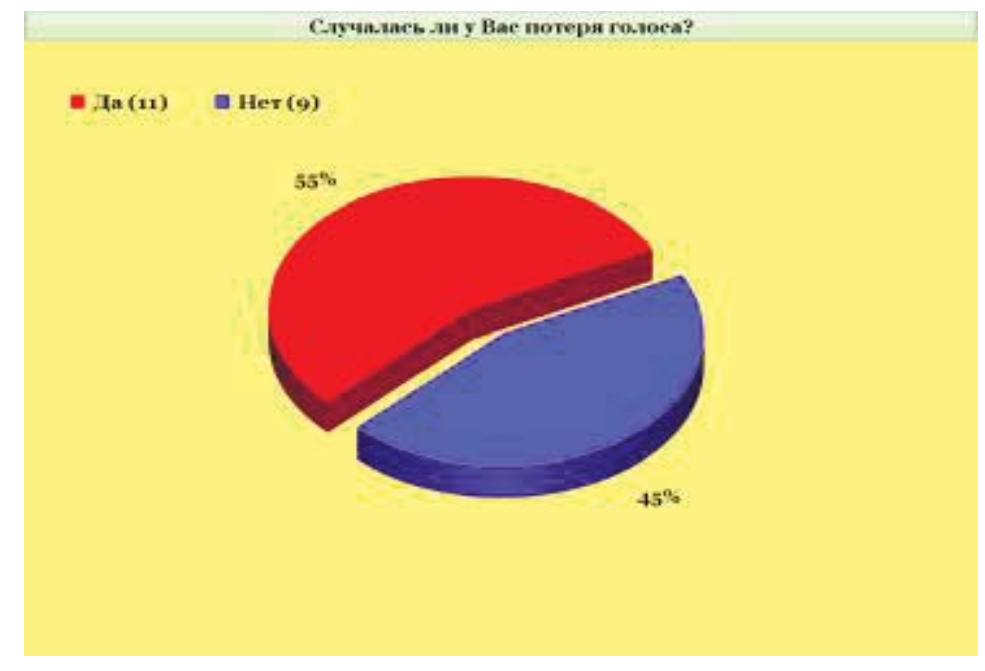

Рис. 3. К вопросу: «Случалось ли у вас потеря голоса?»

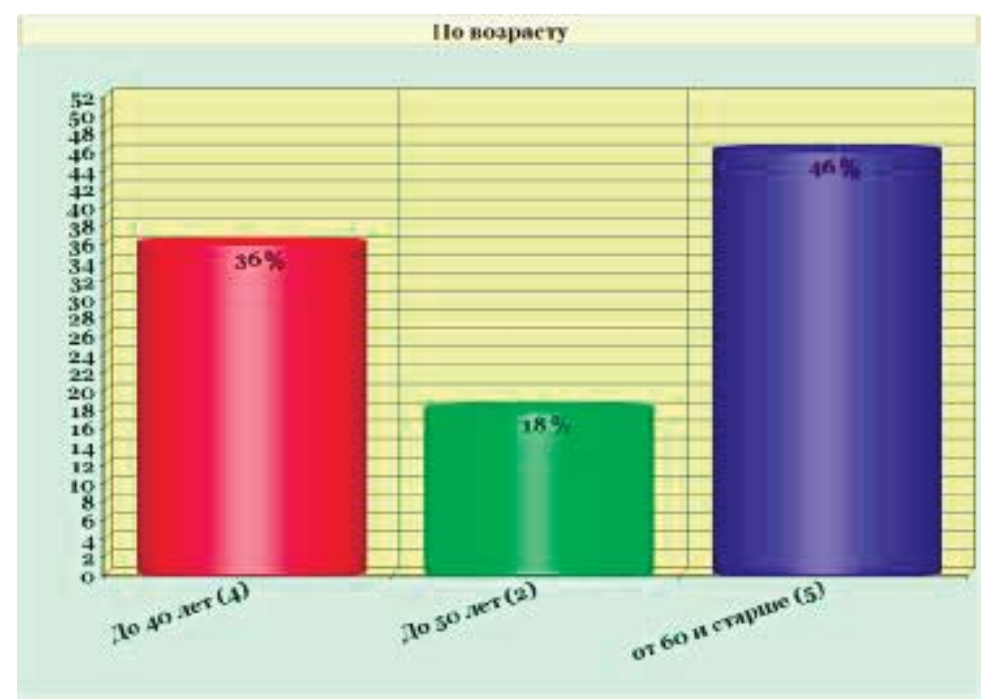

Рис. 4. К вопросу: «Случалась ли у вас потеря голоса?»

Рассмотрев данные следующей диаграммы, которая указывает на возраст преподавателей, то мы можем сказать, что случаи потери голоса в процессе профессиональной деятельности приходятся на возраст до 40 лет (36\%) и старше 60 лет (46\%) (рис. 4,5).

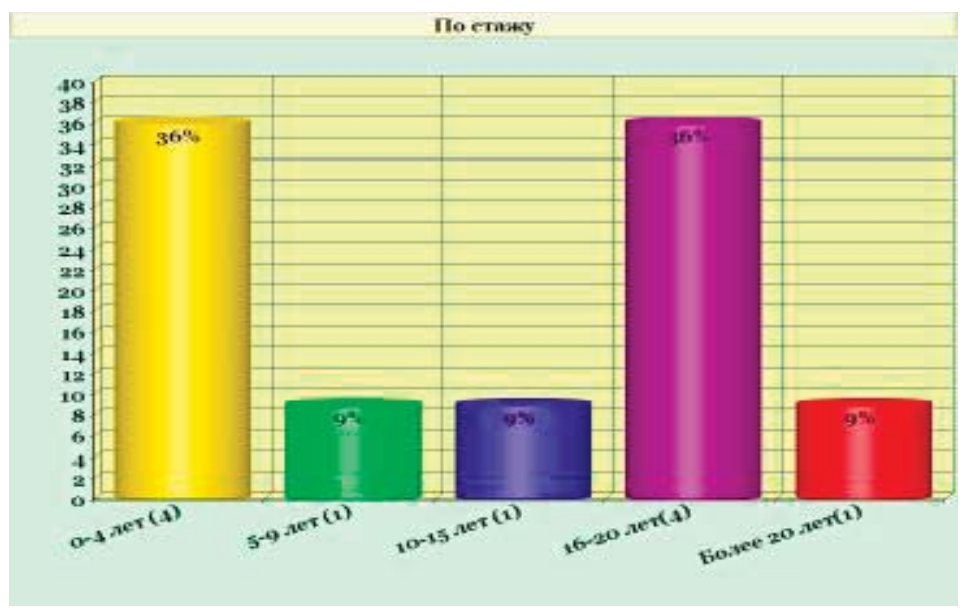

Рис. 5. К вопросу: «Случалась ли у вас потеря голоса?» 
Но, принимая во внимание тот факт, что на должность преподавателя медицинского колледжа приходят специалисты из сферы здравоохранения разных возрастов, мы, в обязательном порядке, проанализировали и следующее: случаи потери голоса в зависимости от стажа преподавательской деятельности. В данном контексте мы подытоживаем, что случаи потери голоса чаще всего встречаются у преподавателей со стажем от 0 до 4 лет (36\%), а также у педагогов со стажем от 16 до 20 лет (36\%) в одинаковом соотношении. Смеем утверждать тот факт, что педагоги с небольшим профессиональным стажем еще не умеют, в достаточной мере, пользоваться возможностями своих резонаторов, не напрягая голосовых связок, а состоявшиеся профессионалы с педагогическим стажем от 16 до 20 лет в силу «изношенности» голосового аппарата, порою, неизбежно сталкиваются с проблемой потери голоса.

Труд преподавателя тяжел и тернист. Подводя итоги научно - практической работы, следует отметить, что все те трудности, с которыми сталкивается педагог в начале свего трудового пути, происходят с ним изо дня в день, из года в год. Казалось бы, что все прописные истины профессиональной деятельности, которые педагог хранит в своей памяти навсегда, должны «сослужить» ему верную службу: фразы на лекциях даваться легко, за словом не нужно «лезть в карман», перелистывая учебное пособие, но отчего - то все проиходит иначе. Педагоги страдают от дисфонии, либо голосовой аппарат совсем не подчиняется их воле - происходит парез голосовых связок. Мы считаем, что эти ситуации возникают лишь оттого, что преподаватель отдает каждому из студентов частицу себя, вкладывая в свой ораторский дар профессионализм, эмоции, душу. И, несмотря на свои недуги, первые тревожные симптомы, характеризующие состояние так называемой предболезни, они все равно ежедневно радуются встрече со студентами.

\section{Список литературы:}

1. Василенко Ю.С., Панкова В.Б., Кудинова О.В. Критерии диагностики профессиональных заболеваний голосового аппарата и вопросы экспертизы трудоспособности // Вести оториноларингологии. - № 5 - 1977, С. 75-77.

2. Морозов А.Б., Симбирцева О.И. и др. Состояние и перспективы развития фониатрической помощи населению РСФСР. Современные методы диагностики и лечения заболеваний гортани. М., 1988; 162168.

3. Вестник оториноларингологии // -№ 5 - 2000, С. 18-21.

\section{Анализ героев олонхо «Эрчимэн Бэргэн» по теории Юнга}

Григорьева С.П., студент, Северо-Восточный федеральный университет, 2. Якутск

E-mail: sqriqorieva31@gmail.com

Научный руководитель: к.ф.н. Архипова E.A.

Якутский героический эпос олонхо является основным жанром в устнопоэтическом творчестве народа саха [1;200]. Олонхо, в образном слове, которого 